\title{
PNAS joins peer-reviewed PubMed Central
}

\section{Washington}

The Proceedings of the National Academy of Sciences (PNAS) will appear on PubMed Central, the US National Institutes of Health's (NIH) new research archive, one month after the publication of the journal. But the academy's governing council will only allow this if research that has not been peer reviewed is kept off the repository.

Nick Cozzarelli, the editor of PNAS, says that the journal will be available on PubMed Central in January for a trial period of a year. He says that subscribers will have electronic access to papers two weeks before publication - six weeks before they become freely available to everyone else.

But the council of the National Academy of Sciences (NAS) said in a statement that "participation in PubMed Central is contingent upon its not including reports that have been screened but not formally peer reviewed". The statement went on to say that non-peer-reviewed material, which the NIH has said could be submitted by any group of three grant-supported researchers, would have to be "completely separate" from peerreviewed material submitted by journals.

"The council felt that making non-peer- reviewed as well as peer-reviewed material available will confuse both scientists and the public," says Ken Fulton, the executive director of the academy. He adds that the degree of separation "remained to be discussed," and that "we haven't had the chance to talk to NIH about what this means".

But some officials at PNAS and the NIH are playing down the condition's significance, saying that PubMed Central will consist entirely of peer-reviewed material when it launches in January. David Lipman, director of the National Center for Biotechnology Information at the NIH and one of the main architects of PubMed Central, says that, although "we want to keep open the possibility" of publishing material prior to peer review, "all of our work is going into the peerreviewed side" in the run up to the launch. "The nonpeer-reviewed side is just not where the interest is."

Lipman said that the NAS statement was "completely consistent with our plans" and that any unreviewed material would appear under a different name, "such as PubMed Unreviewed".

PNAS, a general-interest, biweekly journal with an international circulation of 10,000 and an emphasis on molecular biology, is the second major journal to join PubMed Central. Molecular Biology of the Cell, the journal of the American Society of Cell Biology, will also participate, as will half a dozen smaller journals.

Some geneticists, such as Pat Brown of Stanford University in California, advocate a preprint server for the life sciences community, analogous to the one that Paul Ginsparg runs for physicists at the Los Alamos National Laboratory in New Mexico.

But biologists are unaccustomed

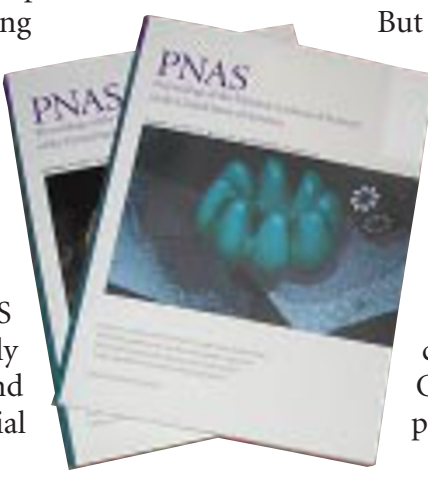
to the idea of wide circulation of preprints, and worry about the proliferation of junk medical science on such a server. The NAS council also said that it would form a committee "to consider the consequences of PubMed Central on science and science publishing". Colin Macilwain

\section{Funding changes aim to reform German universities}

Munich

Germany's Bund-Länder Kommission (BLK), which negotiates joint financing of education and research between federal and state governments, will discuss next week the implementation of a new special fund for financing reforms in universities and other higher-education institutions.

The programme, to be launched in 2001, will increase the number of women in top academic jobs, promote the technically orientated higher education establishments known as Fachhochschule, and improve research infrastructure in east Germany. It will also earmark funds for improving information technology in universities and for modernizing university management and organization.

The latter moves are intended to encourage universities to become more competitive. They include paying professors according to performance and reorganizing faculties and departments to facilitate interdisciplinary teaching and research.

The programme will be the fourth in a series which, until now, have been called Hochschulsonderprogramm (HSP). Although Länder (state) governments are responsible for universities, the HSPs offer a mechanism for the federal government to provide additional funding in areas it wants to promote.

In the past, federal and Länder governments have contributed equally to HSP financing. But the new Social Democrat-Green coalition federal government wants to drop the name HSP and introduce the measures on an annual basis, instead of the four- or five-year basis of previous programmes. It is prepared to provide DM420 million (US\$234 million) for 2001. It also wants to take over full funding of some of the measures designed to promote competition in universities.

A decision may not be reached next week, as Länder governments are reluctant to give the federal government full responsibility for any part of university policy, seeing it as an erosion of their constitutional rights.

A total of DM60 million per year is likely to be set for boosting the role of women in academic life, similar to the sum for this in HSP3, which expires next year. The money will be used to introduce gender studies more widely in universities, to increase the number of female students on scientific and technological courses and, most important, to increase the chances of women qualifying for top academic positions.
According to the plans put forward by the research ministry, less than 15 per cent of the new funds should be used to support $\mathrm{PhD}$ programmes, on the grounds that women are well represented at this level. The ministry proposes measures to increase the representation of women at higher levels, including the creation of short-term group leader positions to give women experience in leading research teams.

The ministry is proposing earmarking professorships for women by paying for the overlapping years of a number of duplicate professorships for women - an approach already used to provide posts for young researchers before the retirement of those occupying senior positions.

The federal research ministry did not want to extend the funding of research infrastructure in east German universities provided for in HSP3. But the eastern Länder have persuaded it that a significant gap still exists between east and west. The new programme now foresees DM20 million per year to help bridge the gap.

Josef Lange, general secretary of the German University Rectors' Conference, broadly welcomes the proposals but says that all HSP measures should lead to stable changes in universities.

Alison Abbott 